\title{
Exploration of Students' Understanding of Geometry Concepts
}

\author{
Rio Fabrika Pasandaran ${ }^{1 *}$, Indah Suciati ${ }^{2 *}$, Alfisyahra ${ }^{3 *}$ \\ ${ }^{1}$ Program Studi Pendidikan Matematika, Universitas Cokroaminoto Palopo \\ ${ }^{2}$ Program Studi Pendidikan Matematika, Universitas Alkhairaat Palu \\ ${ }^{3}$ Program Studi Pendidikan Matematika, Universitas Tadulako \\ Alamat lengkap \\ *Corresponding Author. e-mail: riolovemath@gmail.com; ndahmath@gmail.com; \\ alfisyahra27@gmail.com
}

\begin{abstract}
This article contains an exploration of conceptual understanding in geometry lectures in the Elementary School Teacher Education Study Program, Cokroaminoto Palopo University, Odd Semester, Academic Year 2020/2021. This research was conducted through a qualitative approach with the aim of explaining the details of the relationship between concepts in detail and recommending appropriate learning in problem solving. Data were collected using observation, documentation, and written tests. The three techniques are elaborated with the aim of analyzing the concepts and problem-solving patterns of the students' final semester test results. The results of the study explain several findings, namely, Teaching geometry should begin with the process of identifying the important concepts that build up a particular problem. These concepts are then analyzed and linked to one another to form a network. The concept network is then represented in an image/visual display. Through this visual display, lecturers can guide students in compiling procedural steps based on the sequence of concepts that have been compiled. Lecturers need to create meaningful learning for students by connecting previous knowledge with new knowledge through various representations, examples, and manipulations and focus on conceptual understanding rather than procedures or rules.
\end{abstract}

Keywords: exploration, conceptual understanding, geometry

\section{Eksplorasi Pemahaman Konsep Geometri Mahasiswa}

\begin{abstract}
Abstrak
Artikel ini memuat eksplorasi pemahaman konsep dalam perkuliahan geometri pada Program Studi Pendidikan Guru Sekolah Dasar Universitas Cokroaminoto Palopo Semester Ganjil Tahun Akademik 2020/2021. Penelitian ini dilakukan melalui pendekatan kualitatif dengan tujuan untuk menjelaskan rincian hubungan antar konsep secara detail, dan merekomendasikan pembelajaran yang tepat dalam pemecahan masalah. Data dikumpulkan menggunakan teknik observasi, dokumentasi, dan tes tertulis. Ketiga teknik tersebut dielaborasi dengan tujuan Hasil penelitian menjelaskan beberapa temuan yakni; pengajaran geometri harus diawali dengan proses identifikasi konsep-konsep penting yang membangun masalah tertentu. Konsep-konsep tersebut selanjutnya dianalisis dan dihubungakan satu sama lain sehingga membentuk sebuah jejaring. Jejaring konsep selanjutnya direpresentasikan ke dalam gambar/tampilan visual. Melalui tampilan visual ini, dosen dapat membimbing mahasiswa dalam menyusun langkah-langkah prosedural berdasarkan urutan konsep yang telah disusun. Dosen perlu menciptakan pembelajaran yang bermakna bagi mahasiswa dengan cara menghubungkan pengetahuan sebelumnya dengan pengetahuan yang baru melalui berbagai representasi, contoh, dan manipulasi dan fokus pada pemahaman konseptual dibandingkan prosedur atau aturan.
\end{abstract}

Kata Kunci: eksplorasi, pemahaman konsep, geometri

How to Cite: Pasandaran, R. F., Suciati, I., \& Alfisyahra. (2021). Exploration of students' understanding of geometry concepts. Jurnal Penelitian Ilmu Pendidikan, 14(2), 148-157. doi: https://doi.org/10.21831/jpipfip.v14i1.39562.

Received 22-03-2021; Received in revised from 19-05-2021; Accepted 03-08-2021 


\section{INTRODUCTION}

Mathematics is a field of science that is very important in various aspects of life and other of science. This causes students to be required to be able to learn and understand related concepts in the field of mathematics. Concepts in mathematics can be demonstrated or explained by geometric representations. The concept of geometry as a branch of mathematics can be obtained through a learning process that involves logical thinking skills, procedural/manipulating skills, and deep conceptual \& relational knowledge. Hodiyanto \& Santoso (2019) explained that learning geometry means training our reasoning style critically and evaluatively. These two things are identical to the process of absorbing, remembering, and applying concepts in problem solving and estimating the right and wrong of a concept.

Gulkilik, Kaplan, \& Emul (2019), explained that the essence of mathematics is to work with representations. Therefore, students must understand the form of each representation that works on a concept. On the other hand, they must also be good at connecting one form of representation to another if they work mathematically. Asnawati \& Dewi (2016) explained that mathematical activities include students being given problems related to mathematical reasoning. The problems given relate to how students construct arguments, prove a formula, relate the nature and relationship of facts to analyze a problem.

However, while working mathematically, achieving the ability to understand concepts and problem solving becomes an interesting issue to discuss. The results of Fonna \& Mursalin's research (2018) explain that the achievement of students' mathematical abilities has problems when they do not understand the relationship between concepts, ideas, or materials to be represented. Based on these problems, we were able to collect some equivalent facts that were identified in Geometry lectures for students of the FKIP UNCP Elementary School Teacher Education Study Program, namely 85\% of students only read material without being based on adequate prior knowledge, students work without clear concepts and procedures, students have not been able to create networks and representations of concepts. Sometimes students are found who can perform mathematical operations/procedures but are not accompanied by the correct understanding of concepts. On the other hand, there are students who have conceptual understanding, but are weak in algebraic manipulation.

Based on these five facts, we assess that the learning of geometry in our class experiences fluctuating dynamics. These dynamics are interesting to explore more deeply to reveal more objective and accurate learning facts. Therefore, the focus of research is based on the development of mathematical thinking skills. Based on the opinion of Shafer and Foster (Wardhani, 2015), who propose three levels of mathematical thinking, namely the level of reproduction, connection, and analysis. The reproduction level is the lowest level of thinking, while analysis is the highest level of thinking. The following are the components of each level of thinking include; Reproduction level includes, knowing basic facts, applying standard algorithms, developing technical skills, Connection level covering, integrating information, making connections within and between mathematical domains, establishing formulas (tools) that will be used to solve problems, and solving non-routine problems, and Analysis level includes, mathematizing situations, conducting analysis, interpreting, developing their own models and strategies, developing mathematical arguments and making generalizations.

Based on the description, it can be concluded that the three levels of thinking above are essentially non-procedural thinking abilities but are more focused on conceptual abilities. The three levels of thinking can be described as the ability to find and explore patterns to understand mathematical structures and the underlying relationships, the ability to use the available facts effectively and appropriately to formulate and solve problems, the ability to make mathematical ideas meaningfully, the ability to think and solve problems. reasoning flexibly through the preparation of conjectures, generalizations, and justifications, and the ability to determine that a problem-solving result is reasonable or logical. Based on the background of the problem, the purpose of this study is to 
explore the thinking process of students in understanding the concept of geometry as well as to describe learning strategies that can build an understanding of the concept of geometry systematically.

\section{METHODS}

Based on the description, it can be concluded that the three levels of thinking above are essentially non-procedural thinking abilities but are more focused on conceptual abilities. The three levels of thinking can be described as the ability to find and explore patterns to understand mathematical structures and the underlying relationships, the ability to use the available facts effectively and appropriately to formulate and solve problems, the ability to make mathematical ideas meaningfully, the ability to think and solve problems. reasoning flexibly through the preparation of conjectures, generalizations, and justifications, and the ability to determine that a problem-solving result is reasonable or logical. Based on the background of the problem, the purpose of this study is to explore the thinking process of students in understanding the concept of geometry as well as to describe learning strategies that can build an understanding of the concept of geometry systematically.

After the data is collected, it is continued with the data validation process through triangulation. Triangulation is done by looking at the suitability of the data from each research instrument. The collected data will be reviewed for its consistency properties. Data that is consistent/relatively the same is valid data and can be continued with the data analysis process. Data analysis was carried out using the Miles and Huberman technique (Data Collection, Data Reduction, Data Display, Data Verification) interactively and continuously to obtain a patterned form of data, with the following steps.

a. Collecting data through field notes, learning transcripts, and videos of learning observations.

b. Data reduction is an activity that refers to the process of selecting, focusing, abstracting, and transforming raw data. Data reduction in this research is done by making a summary consisting of core, process, and statements that are in accordance with the research objectives. The data validation technique used in this study is an extension of observation

c. Presentation of data which includes classification and identification of data, namely writing organized and categorized data sets to produce valid data.

d. Presentation of data and interpretation of data, contains a discussion of valid data to produce research findings based on the research objectives setmetode ini. Penulis disarankan menyampaikan sumber rujukan atas metode yang digunakan.

\section{Result}

\section{RESULT AND DISCUSSION}

The tests were carried out to get a comprehensive picture of problem solving for 37 students. The test given is in the form of a description ( 2 points) which contains material for proving the basic theorems of geometry. From this test, there are two responses/answers to the students' written test results which we consider quite interesting and can provide information that is relevant to the purpose of this study. The full description can be seen as follows.

Problem 1

Complete the prove of theorem below.

If $\angle 1 \cong \angle 3$, then $\angle M O P \cong \angle N O Q$

Figure 1 describes the two subjects. The description of the following answers contains the thought processes of subject (1) and subject (2) in constructing a simple proof of the relationship between angles. The answers to both are described in the stages of proof and followed by the underlying reasons. 
Jurnal Penelitian Ilmu Pendidikan, 14 (2), 2021 - 151

Pasandaran, Suciati, \& Alfisyahra

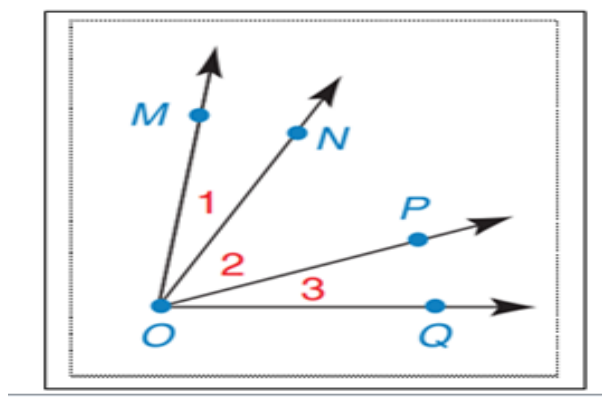

Figure 1. Problem 1

Based on the results of the work of the two subjects at Figure 2, several facts can be described including in step (1) both subjects start problem solving by writing down the known information. Step (2), both subjects can write down new ideas in the form of similarities that contain the sum of two angles. This idea arose because of the information in the image. Furthermore, in step (3), the two subjects did the same thing in step (2) but differed in the form of similarity produced. Based on the information/ideas obtained from steps (2) and (3), the two subjects combined the two to obtain the intended evidence.

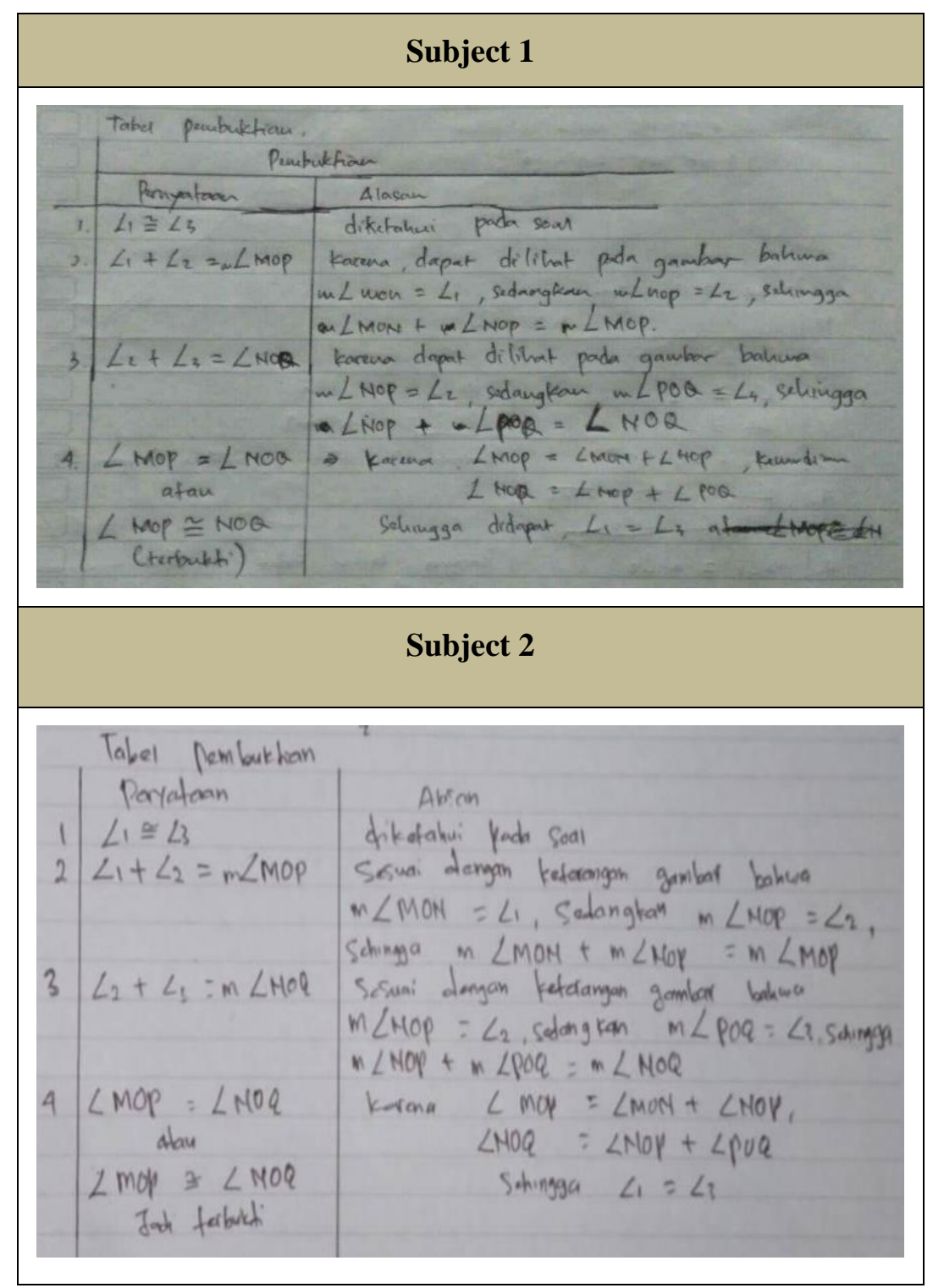

Figure 2. The results of the work of the subject on the problem 1 
Problem 2

Complete the prove of theorem below.

If $\angle 1 \cong \angle 2, \angle 3 \cong \angle 4$, and $\angle 2+\angle 3=90^{\circ}$, then $\angle 1+\angle 4=90^{\circ}$ !

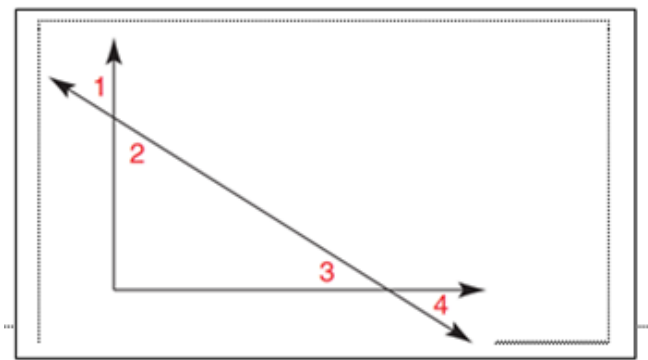

Figure 3. Problem 2

Figure 3 describes the two subjects. The description of the following answers contains the thought processes of subject (1) and subject (2) in constructing a simple proof of the relationship between angles. The answers to both are described in the stages of proof and followed by the underlying reasons

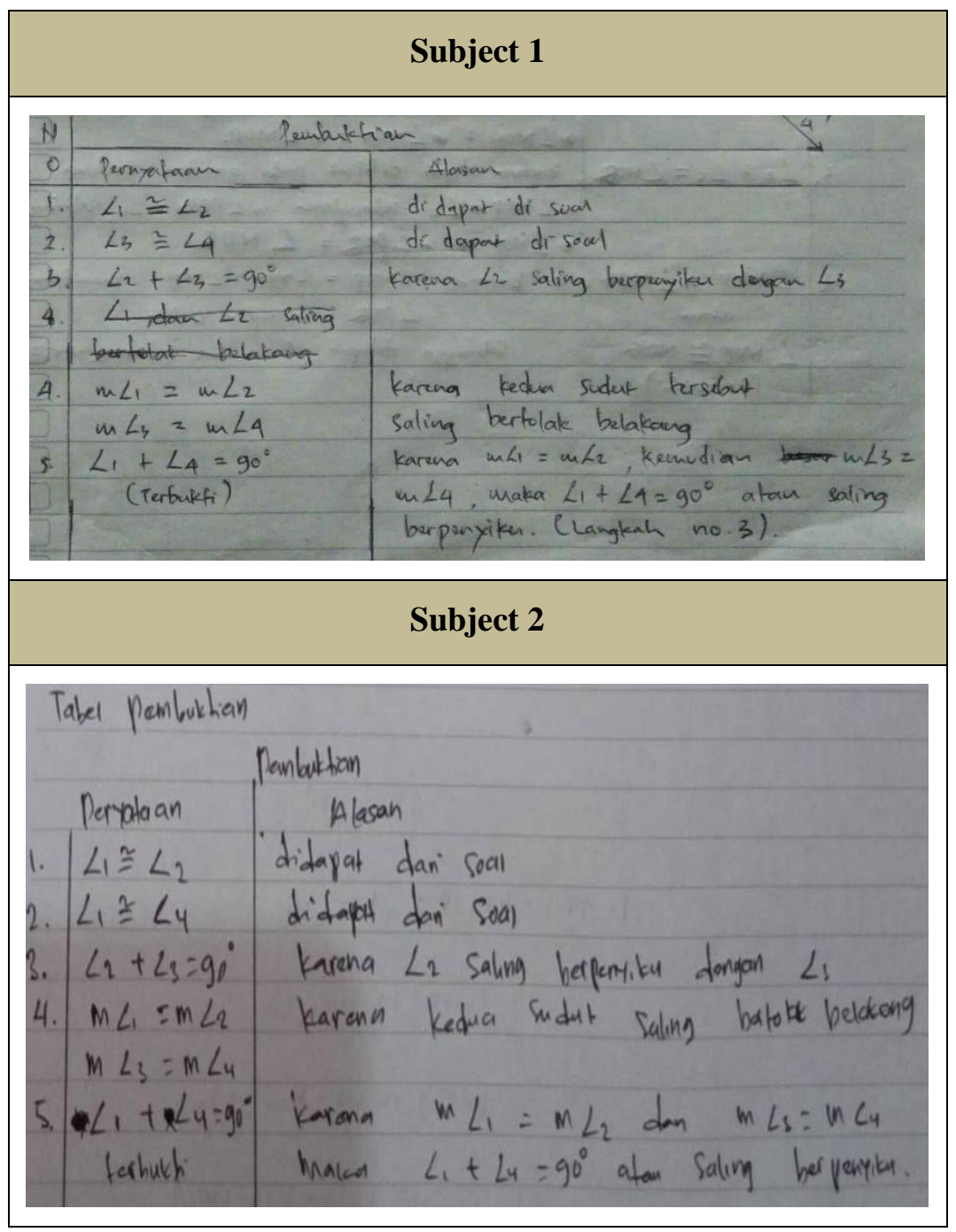

Figure 4. Subjects' work results on problem 
From the exposure of the work of the two subjects in problem 2 (Figure 3), several facts were obtained including in steps ( 1 and 2 ) both subjects started problem solving by writing down the known information. Steps (3 and 4), both subjects can write down new ideas in the form of similarities that contain the sum of two angles. This idea arose because of the information in the image. Furthermore, in step (5), based on the information/ideas obtained from steps (4) and (5), the two subjects combined the two so that the intended evidence was obtained. The information is explained at Figure 4.

\section{Discussion}

Solving the problem (1), both subjects did proof of the theorem by writing several statements in sequence and equipped with the underlying reasons. Based on the problem, the subject wrote down the similarity of sizes 1 and 3 . In the second statement, the subject wrote down the sum of the two angles ( 1 and 2 ) into MOP. The subject also did the same thing by adding up the angles (2 and 3$)$ to become NOQ. The process of writing a statement of facts is an indication that the two subjects searched for information related to the basic facts and principles contained in the questions. Each information is presented back in writing and is equipped with a calculation algorithm. This is part of the process of understanding mathematical concepts systematically. In line with this, Hodiyanto \& Santoso (2019), explained that mathematical understanding is a basic competency in learning mathematics which includes: the ability to absorb material, remember formulas and be able to apply ideas in problem solving on an ongoing basis. There are three core activities in understanding concepts, namely absorbing information, understanding information, and carrying out applications. In addition, the subject also wrote down the reasons that these two facts were obtained from the information in the picture. At the end, the subject writes down the similarity relationship in statement (2) and statement (3) to conclude that the MOP angle is the same as the NOQ angle. The process of connecting several ideas into one more complex idea is an indication of reasoning.

The two subjects describe the relationship of the concepts that they arrange in the form of logical reasons at each step of the proof. In addition, to complete this process, they also perform the operation of adding two angles and recognizing certain angles that have the same size. This process is two things that happen continuously. It begins with a systematic understanding of concepts and ends with the use of mathematical procedures to obtain facts/results. In line with the results of the research by Pasandaran \& Kartika (2019) that thinking is a mental process that takes place continuously. The process carried out by the two subjects is to acquire knowledge and manipulate knowledge through activities of remembering, analyzing, understanding, judging, reasoning, imagining, and speaking. These thinking skills can have the opportunity to build students' higher order thinking skills. In line with this, Bosse, Young, Bayaga, Davis, DeMarte, \& Fountain (2020) also explain that higher order thinking processes related to student problem solving are complex but can be observed, described, and categorized. This process is used by both subjects in identifying implied concepts through the problem-solving tasks presented. This fact can shape the variety of thought processes about how they solve problems in the context of a dynamic mathematical environment.

Higher order thinking is closely related to the process of using mathematical representations. In line with this, the results of Pasandaran \& Baharuddin (2016) research which explains that representation is a description of the relationship between objects and abstract symbols, so this fact is an indication that is relevant and true. Both subjects describe visual objects in the form of images into basic elements that represent certain concepts. Krajcevski \& Sears (2019) explains that visual objects are sometimes needed to articulate the need for a new mathematical idea, especially when we do not have a more precise analytical description of the idea. Visual objects can also be used as intermediaries between the symbolic and verbal representations of some mathematical objects and will strengthen students' ability to manipulate and express analytically some of the properties of the objects they represent.

In Geometry, each visual object is an attribute for building conceptual understanding through the representation of mathematical ideas (Krajcevski \& Sears, 2019). A visual image, representation or experience that is often remembered for a particular thing is called a concept picture, while a verbal definition that can be remembered about a particular concept is called a concept definition. Both 
subjects tend to transform the form of ideas they have. In this case the subject tries to communicate his ideas into the language of symbols. For that, the subject requires a physical representation, namely an external representation, in the form of algebraic symbols called variables. This finding is also in line with the research results of Bossé, Bayaga, Fountain, \& Young (2019) which explains that mathematical representation is a manifestation of the form of communication of mathematical ideas. This is done by connecting an idea with various kinds of references in the form of certain theorems/definitions/or lemmas. This process can further build investigative abilities for students, namely efforts to carry out systematic investigations in problem solving. Starting from data collection, data analysis, data synthesis and verification of results or conclusions. Furthermore, this fact is in line with the substantive finding that students can network concepts systematically through what they see and what they understand. These two things become the basis for them to represent the concept from figural to algebraic representation (Pasandaran \& Mufidah, 2020).

Problem solving (2), subject 1 writes down several steps of proof and is accompanied by the underlying reasons. The first three statements, the subject writes down three pieces of information that have been known from the problem. In the fourth step, the subject wrote the similarity of two pairs of angles ( 1 and 2) and angles ( 3 and 4) as two pairs of opposite angles with the same measure in each pair. In the fifth statement, the subject concludes that based on statements (3) and (4), a pair of angled angles (1 and 4) are obtained. Subject 2 also tends to do the same thing in steps (1) to (4) but is different in step (5). In this step, subject 2 only refers to step (4), which is about the similarity of the sizes of two pairs of angles and ends with the conclusion that angles (1 and 4) are right angles. Based on the equivalence of the identified facts, both subjects showed a tendency to think systematically, starting from the reproduction of concepts, connections between concepts and analysis. This finding is in line with the results of Adirakasiwi \& Warmi's research (2018), which explains that students tend to use their visuals to identify the properties or relationships of concepts in problems. After that, do the sequencing of concepts, tracing the causal relationship from one concept to another so that it can develop a strategy of deductive proof. Several reasons they wrote can be seen as a form of accuracy in realizing the workings of the principles of proof in geometry.

Proving geometric theorems is not an easy process. Axiomatic deductive thinking skills are required. There are two mathematical proof strategies proposed by Mahfudy (2017), namely (1) a proof strategy on geometry problems with a syntactic proof production type, including identifying and manipulating statements or information in problems, translating information in problems, choosing theorems. or related or relevant propositions, using symbols or formal mathematical notations in carrying out the proof stages, using the help of sketches, and drawing conclusions from each statement that has been obtained and (2) proof strategies on geometric problems with the type of semantic proof (semantic proof production). among others, is to use their intuition to make assumptions, conjectures or estimates that are considered correct and to reason on the assumptions made and use sketches to help facilitate proof. If it is related to the research results, the activities of the two subjects in compiling proofs tend to be identical to the syntactic proof strategy. The proof process they do only focuses on identifying and manipulating the structure of an argument, as well as selecting the relevant theorems or axioms without making assumptions based on intuition or evaluating the steps of their proof. Furthermore, Weber \& Alcock (2004) stated that proof by means of syntax occurs when drawing conclusions based on the manipulation of symbolic formulas in a logical way. In addition, this proof strategy works when there is a process of correctly identifying mathematical concepts to guide the preparation of formal conclusions.

To minimize the problems that have been described previously, an appropriate learning strategy is needed to assist in building mathematical thinking skills in solving Geometry problems. The ability to think mathematically is divided into three levels, namely the level of reproduction, the level of connection, and the level of analysis. The reproduction level focuses on basic fact knowledge, application of standard algorithms, and skills development. Concept understanding is very necessary at this level, so that according to Ausubel (Suciati, 2019) that learning concepts can be done with two approaches, namely a cognitive approach and a behavioral approach. The use of media/applications is also very necessary in learning. The learning process must also be student-centered, so that students are not passive. One way that can be used at this level is to use the Think-Talk-Write strategy. According to Ainy (2009), the Think-Talk-Write learning strategy is divided into three stages, namely 
the think stage where information is processed cognitively, the talk stage, namely the skill in expressing opinions based on the understanding that students know, and the writing stage where the information generated is made in note form. In addition, there are also several alternative steps that have been taken to build students' understanding of mathematical concepts, especially in geometry. Like the research that has been done by Pratiwi (2016) that learning the 5E Learning Cycle with the help of Geogebra can improve the ability to understand mathematical concepts. In line with Pratiwi's research, the same research was also conducted by Sudarman \& Vahlia (2016) which showed that the Quantum Learning learning method was effectively used on students' mathematical concept understanding abilities with the help of the Tandur framework.

The level of connection is a higher level than the level of reproduction. Where at this level focuses on integrating information, making connections within and between mathematical domains, determining formulas that will be used to solve routine and non-routine problems. At this level, the use of media/applications can still be given. As done by Supriadi (2015) that using Geogebra in geometry learning is proven to significantly improve students' mathematical communication skills, critical and creative attitudes. In line with that, Lydiati (2020) revealed that there was an increase in mathematical connections by using the REACT learning strategy assisted by batik media in geometry transformation material.

At the analysis level, which is the highest level, it focuses on mathematicising the situation, conducting analysis and interpretation, developing models and strategies, as well as developing mathematical models and generalizing. According to Budiarto \& Artiono (2019) that at this level mediation learning is very suitable for a learning activity to recognize, assemble, and construct existing information. As revealed by Rahman \& Yunita (2018) in their research which explains that the PACE learning model (Project, Activity, Cooperative Learning, and Exercise) can improve students' ability to prove geometry. In addition, Konita, Asikin, \& Asih (2019) stated that one of the learning strategies so that students can have the ability to use mathematical reasoning, perform mathematical manipulations, generalize, and compile evidence or explain mathematical ideas and statements can use the CORE learning model. (Connecting, Organizing, Reflecting, and Extending).

We can do learning strategies by considering the level of students' thinking processes in building geometric problem solving. To improve students' understanding and mathematical thinking skills. If it is associated with proving geometry problems, transactive reasoning activities will help students make assumptions based on intuition and evaluate the proof steps they have compiled so that students are not only able to choose related theorems or theorems and use symbols or formal mathematical notation in carrying out the proof stages. The learning syntax with abductive-deductive strategies is orientation to problems, organizing for learning, analyzing, and evaluating processes, generalizing the findings obtained, and discussing more problem strategies (Shodikin, 2015).

Peirce (Supianti \& Sari, 2016) states abduction is reasoning that aims to find patterns in phenomena by doing hypotheses. Abduction is a type of critical thinking rather than symbolic logic. Furthermore, Peirce (Supianti \& Sari, 2016) argues that a deductive method is an approach with conclusions drawn from general laws, theories, or hypotheses. The abductive-deductive learning strategies complement each other because the development of reasoning abilities which is the main characteristic of the abductive approach cannot completely answer the problem, but the process offers reasons as a basis for certain actions until finally conclusions can be made using a deductive approach. The activity of providing logical reasons at each step of proof is an effort to collect facts to be able to make a conclusion as Shodikin (2015) stated that the general basis that must be possessed in solving mathematical problems is the ability to understand and formulate facts that will become the final target of a given problem.

Students' reasoning abilities must always be developed because students who have mathematical reasoning abilities will more easily understand mathematical concepts as a whole and train students' thinking to be more critical so that they can make conclusions about mathematical problem-solving problems as well as geometric proof questions. This is in line with Sumartini (2015) which states that the process of mathematical thinking in compiling a conjecture, compiling evidence, manipulating mathematical problems, making a conclusion, and compiling a new statement based on statements that have been proven previously is an understanding of mathematical reasoning ability. 


\section{CONCLUSION}

Based on the results of the research and discussion, it can be concluded that in proving the problem of geometry, the subject understands mathematical concepts systematically by searching for information related to the basic facts and principles contained in the problem. This fact is identical to the reproductive thinking level which includes, knowing basic facts, applying standard algorithms, developing technical skills. Each information is presented back in writing and is equipped with a calculation algorithm. Subjects tend to transform the form of ideas they have into symbolic language. The subject writes down the logical reasons underlying the subject's statement at each proof step, then sequences the concepts, and traces the causal relationship from one concept to another to produce a conclusion. This fact is identical to the level of connection thinking; integrate information, make connections within and between mathematical domains, define formulas (tools) that will be used to solve problems, and solve non-routine problems.

The strategy that the subject does in building geometry problem-based learning in this case is compiling proof of geometry problems as a syntax proof strategy. The proof process that the subject does only focuses on identifying and manipulating the structure of an argument, as well as selecting the relevant theorems or axioms without making assumptions based on intuition or evaluating the activities of evaluating the proof steps they have compiled.

The arrangement of concepts is then analyzed and related to each other to form a network. The concept network is then represented in a visual image/display. Through this visual display, lecturers can guide students in compiling procedural steps based on the sequence of concepts that have been compiled. Lecturers need to create meaningful learning for students by connecting previous knowledge with new knowledge through various representations, examples, and manipulations and focusing on conceptual understanding rather than procedures or rules.

\section{REFERENCES}

Adirakasiwi, A. G. \& Warmi, A. (2018). Analisis tingkat berpikir mahasiswa berdasarkan teori Van Hiele ditinjau dari Gaya Kognitif. JP3M: Jurnal Penelitian Pendidikan dan Pengajaran Matematika, 4(1), 1-6. https://doi.org/10.37058/jp3m.v4i1.465.

Ainy, C. (2009). Strategi meningkatkan pemahaman konsep dan kemampuan komunikasi matematika. Didaktis, 8(3), 14 - 19. http://dx.doi.org/10.30651/didaktis.v9i3.245.

Asnawati, S. \& Dewi, I. L. K. (2016). Penggunaan teknik murder pendekatan metakognitif untuk meningkatkan penalaran matematis mahasiswa pendidikan matematika pada matakuliah geometri analitik. TEOREMA: Jurnal Teori dan Riset Matematika, 1(1), 2-7. http://dx.doi.org/10.25157/teorema.v1i1.535.

Bossé, M. J., Bayaga, A., Fountain, C., \& Young, E. S. (2019). Mathematical representational code switching. International Journal for Mathematics Teaching and Learning, 20(1), 33-61. https://www.cimt.org.uk/ijmtl/index.php/IJMTL/article/view/141.

Bosse, M. J., Young, S. E., Bayaga, A., Davis, L. K., DeMarte, A., \& Fountain, C. (2020). Cognitive processes in problem solving in a dynamic mathematics environment. International Journal for Mathematics Teaching and Learning, 21(2), 174-196.

Budiarto, M. T. \& Artiono, R. (2019). Geometri dan permasalahan dalam pembelajarannya (Suatu penelitian meta analisis). JUMADIKA: Jurnal Magister Pendidikan Matematika, 1(1), 9 - 18. https://doi.org/10.30598/jumadikavolliss1year2019page9-18.

Fonna, M. \& Mursalin, M. (2018). Pengembangan modul geometri analitik bidang berbantuan wingeom software studi pendidikan matematika Universitas Malikussaleh. Union: Jurnal Ilmiah Pendidikan Matematika, 6(3), 391-402 . http://dx.doi.org/10.30738/union.v6i3.2988.

Gulkilik, H., Kaplan, H. A., \& Emul, N. (2019). Investigating the relationship between argumentation and proof from a representational perspective. International Journal for Mathematics $\begin{array}{llll}\text { Teaching and } \quad \text { Learning, } & \text { 131-148. }\end{array}$ https://www.cimt.org.uk/ijmtl/index.php/IJMTL/article/view/211. 
Hodiyanto \& Santoso, D. (2019). Geometer's sketchpad (gsp) dan pemahaman konsep geometri analitik bidang. Kreano: Jurnal Matematika Kreatif-Inovatif, 10(2), 153-158. https://doi.org/10.15294/kreano.v10i2.20560.

Konita, M., Asikin, M., \& Asih, T. S. N. (2019). Kemampuan penalaran matematis dalam model pembelajaran connecting, organizing, reflecting, extending (core). PRISMA, Prosiding Seminar Nasional Matematika, 2, 611-615. Retrieved from https://journal.unnes.ac.id/sju/index.php/prisma/article/view/29072.

Krajcevski, M. \& Sears, R. (2019). Common visual representations as a source for misconceptions of preservice teachers in a geometry connection course. International Journal for Mathematics $\begin{array}{llll}\text { Teaching and } & \text { 20(1), } & \text { 85-105. }\end{array}$ http://www.cimt.org.uk/ijmtl/index.php/IJMTL/article/view/189.

Lydiati, I. (2020). Peningkatan koneksi matematis pada materi transformasi geometri menggunakan strategi pembelajaran react berbantuan media motif batik kelas xii ips 1 sma negeri 7 Yogyakarta. Ideguru: Jurnal Karya Ilmiah Guru, 5(1), 25-33. https://doi.org/10.51169/ideguru.v5i1.109.

Mahfudy, S. (2017). Strategi pembuktian matematis mahasiswa pada soal geometri. Jurnal Teori dan Aplikasi Matematika, 1(1), 31-40. Retrieved 12 March, 2021, from https://www.neliti.com/publications/274390/strategi-pembuktian-matematis-mahasiswa-padasoal-geometri.

Pasandaran, R. F. \& Baharuddin, M. R. (2016). Profil berpikir dalam menyelesaikan masalah aljabar berpandu pada taksonomi solo ditinjau dari tingkat efikasi diri pada siswa smp Al-Azhar Palu. Pedagogy, 1(1), 86-96. http://dx.doi.org/10.30605/pedagogy.v1i1.262.

Pasandaran, R. F. \& Kartika, D. M. R. (2019). Higher order thinking skill (hots): Pembelajaran matematika kontemporer. Pedagogy, 4(1), 53-62. http://dx.doi.org/10.30605/pedagogy.v4i1.1429.

Pasandaran, R. F. \& Mufidah (2020). Studi kasus pembelajaran geometri analitik. Pedagogy, 5(2), 91105. https://doi.org/10.30605/pedagogy.v5i2.413.

Pratiwi, D. D. (2016). Pembelajaran learning cycle 5e berbantuan geogebra terhadap kemampuan pemahaman konsep matematis. Al-Jabar: Jurnal Pendidikan Matematika, 7(2), 191-202. https://doi.org/10.24042/ajpm.v7i2.34.

Rahman, A. A. \& Yunita, A. (2018). Penerapan model pembelajaran pace untuk meningkatkan kemampuan pembuktian matematika siswa di kelas vii smp materi geometri. MAJU, 5(1), 2738. https://ejournal.stkipbbm.ac.id/index.php/mtk/article/view/104.

Shodikin, A. (2015). Peningkatan kemampuan pemecahan masalah siswa melalui strategi abduktifdeduktif pada pembelajaran matematika. Jurnal Matematika Kreatif-Inovatif, 6(2), 101-110.

Suciati, I. (2019). Penggunaan sajak matematika (cinquains) pada materi bangun datar. Guru Tua: Jurnal Pendidikan dan Pembelajaran, 2(1), 9-16. https://doi.org/10.31970/gurutua.v2i1.18.

Sudarman, S. W., \& Vahlia, I. (2016). Efektifitas penggunaan metode pembelajaran quantum learning terhadap kemampuan pemahaman konsep matematis mahasiswa. Al-Jabar: Jurnal Pendidikan Matematika, 7(2), 275-282. https://doi.org/10.24042/ajpm.v7i2.42.

Sumartini, T, S. (2015). Peningkatan kemampuan penalaran matematis siswa melalui pembelajaran berbasis masalah. Mosharafa Jurnal Pendidikan Matematika, 5(1), 1-10.

Supianti, I \& Sari N, M. (2016) Pembelajaran matematika dengan strategi abduktif-deduktif untuk meningkatkan advanced mathematical thinking mahasiswa. Prosiding Seminar Nasional Matematika Universitas Siliwangi, 107-114.

Supriadi, N. (2015). Pembelajaran geometri berbasis geogebra sebagai upaya meningkatkan kemampuan komunikasi matematis siswa madrasah tsanawiyah (mts). Al-Jabar: Jurnal Pendidikan Matematika, 6(2), 99-109. https://doi.org/10.24042/ajpm.v6i2.20.

Wardhani, I. S. (2015). Menumbuhkan kemampuan berpikir geometri melalui pembelajaran connected mathematics project (cmp). PENA SD: Jurnal Pendidikan dan Pembelajaran Anak Sekolah Dasar, 1(1), 97-105. http://dx.doi.org/10.29100/jpsd.v1i01.431.

Weber, K. \& Alcock, L. (2004). Semantic and syntactic proof productions. Educational Studies in Mathematics, 56(2), 209-234. https://www.jstor.org/stable/4150282?seq=1. 